\title{
Utilization of Unutilized Land on Development of a Demonstration Plot for Rotational Grazing of Black Bengal Goats on Zero to Negligible Budget
}

\author{
R. Bhar ${ }^{1}$, D.C. Roy ${ }^{2}$, M. Ghosh ${ }^{3}$, G.P. Mandal ${ }^{2}$, S. Naskar ${ }^{1}$, T.K. Biswas ${ }^{1}$, \\ D. Mandal ${ }^{1}$, P.S. Banerjee ${ }^{1}$, B. Koli ${ }^{4}$ and P. Biswas ${ }^{2}$ \\ ${ }^{1}$ ICAR-IVRI Eastern Regional Station, Kalyani, Nadia, W.B, India \\ ${ }^{2}$ West Bengal University of Animal and Fishery Sciences, India \\ ${ }^{3}$ ICAR-ERS NDRI, Kalyani, Nadia, W.B, India \\ ${ }^{4}$ Regional Fodder Station, Kalyani, Nadia, W.B, India \\ *Corresponding author
}

\section{A B S T R A C T}

Keywords

Zero budget, Rotational grazing, Black Bengal goat

Article Info

Accepted:

10 October 2019

Available Online:

10 November 2019
Underutilization of some lands at organised and unorganised sectors is often observed. Utilization of assets at farmers' door needs household or hired manpower. An attempt has been made to utilize a portion of unutilized lands without any extra monitory inputs. The land was developed (Fig 1) through successive cumulative activities in four phases, (1) peoples participatory motivational programme through Swachh Bharat Mission: cleaning of the land to make ourselves happier, (2) time to time sprinkling water for the germination and growth of doob grass (Cynodondactylon) along with the other naturally growing grass, (3) fencing of the land on dividing into six plots of 1.37 kathas, each; (4) studies on palatability of naturally grown grasses. Rotational grazing land was developed on utilization of the existing manpower through motivational programme on creating self-help group personnel. Moreover, different consumable articles [viz., bamboos, kanchis/spikes, moringa (sajan), mulberry branches and Tinosporaetc] available within the working environment were utilized, without any monitory expenditure. Different palatable grasses (Crab, Knot, Sursuri /Smut, Finger / hairy crab and Dhoob/Bermuda grass) and herbs (Note sak, Kata note, Borokerui, Graceful pouzol weed/kulkuri and Danta/alligator weed) were naturally grown. Thus, unutilized/underutilized land in organised and unorganised set up could be utilized on application of such model for addressing the livelihood security of under employed youths. Integrated goat husbandry with negligible inputs, seems to be one of the viable alternatives for addressing the livelihood security of landless to marginal farmers.

\section{Introduction}

Utilization of assets needs household or hired manpower. There is a general perception that due to increase in population there is a shortage of land for fodder cultivation for our large and small ruminants. As a result of which our animals often remain underproductive and suffer from protein energy malnutrition and different nutritional 
deficiency diseases. It is the fact that the total human population of Bharat is increasing, but at farmers' door the family sizes are decreasing. Decrease in the number of family members is causing shortage of household manpower for day to day integrated animal husbandry practices which has been practiced generation after generation. As a result, our land and different other assets remain either unutilized or underutilized. There are different reasons for underutilization of assets viz., reduction of family size of farmers and livestock owners, non-availability and high cost of hired labourers, increase in the input cost of agricultural farming etc. (Negi et al., 2015; Bhar et al., 2018). For optimum use of such assets, an optimum family size is required. Utilization of assets for small to medium size integrated animal husbandry practices on hiring manpower would increase the input cost. Under the present study an attempt has been made to utilize a portion of unutilized lands without any extra monitory inputs.

\section{Materials and Methods}

To know the ground realities, a survey was conducted in organised and unorganised sectorsin February, 2018, at Rathtala area of Kalyani, under district Nadia, West Bengal. It has been revealed that underutilization of land and underemployment of different categories of farmers and youths are the areas where the intervention of integrated goat farming would be introduced for addressing the livelihood security of resource poor livestock owners and farmers. On identifying an unutilized area of about 8.2kathas of land in an organised sector, it was decided to develop a demonstration plot for rotational grazing of black Bengal goats on "zero to negligible budget" to reduce the input cost of integrated goat farming.

The land was developed (Fig. 1) through successive cumulative activities in four phases, (1) peoples participatory motivational programme through Swachh Bharat Mission: cleaning of the land to make ourselves happier, (2) time to time sprinkling water for the better germination and growth of doob grass (Cynodondactylon) along with the other naturally growing grass and for creating grazing land, and weeding of other vegetation, relatively unpalatable to goats, (3) fencing of the land on dividing into six plots of 1.37 kathas, each; (4) studies on palatability of naturally grown grasses.

\section{Results and Discussion}

\section{People participatory motivational programme through Swachh Bharat Mission}

It was perceived that the potential of existing contractual labourers was much higher than that of the day to day quantum of work carried out by them. On little motivation and working together on application of different established sociological concepts they were motivated for utilization of a portion of unutilized lands without any extra monitory inputs.

Feeling oneness that everybody felt sorrow on the underutilization of the land, an initiative has been taken to apply the developmental model of Negi et al., (2015) for developing a demonstration plot for propagation of concept of integrated goat farming for addressing the livelihood security of unemployed and underemployed youths.

On creating self-help group (SHG), the targeted area was cleaned through Swatchhata Abhiyan. This was undertaken in reference to the Swachh Pledge taken by the government servants. The existing facilities were gradually organized for integrated goat farming on "zero to negligible monitory inputs", and the situation was improved. On cleaning the area all the workers and SHG personnel were 
happy on significant improvement in the get up of the land.

Sprinkling water for germination and growth of natural grasses

Regularly water was sprinkled over the land to utilize minimum water to save water for drinking of animals and for other purposes. Very soon a green pasture of doob and other natural grasses was developed over the demonstrated area (Fig. 1 and Table 1).

\section{Fencing of the land}

Fencing of the land was done by the available resources of the farm, viz., bamboos, kanchis/spikes, moringa (sajan) and mulberry branches, Tinosporaetc (Fig. 1). Moreover, participation and integration of local villagers /people as SHG personnel were made through collection of moringa and mulberry branches on conducting survey of their unutilized/ underutilized assets. The survey was done with particular reference to the integrated animal husbandry (including poultry), fishery and agriculture system. Fencing of the land was done on dividing into six plots of 1.37 kathas, each, to keep provision of rotational grazing for the kids and their dams/does. The goats were allowed to graze for the two purposes, (i) to study the relative palatability of grasses and leaves available within the fenced environment; (ii) to estimate the availability of nutrients for the goats to calculate the amount of supplementary nutrients to be arranged from outside the grazing land.

\section{Grazing of goats for classifying the natural grasses}

A group of Black Bengal goats of body weight ranging from of about 5.0 to $10.0 \mathrm{~kg}$ was allowed to graze to identify the naturally grown palatable grasses and the herbs. Altogether, thirteen grasses and plants (including herbs) were identified (Table 1). All the grasses were not preferred by the goats. The grasses or herbs which were preferred and readily consumed by the grazing goats were classified as palatable, which were found ten in number; and the herbs or weeds not readily preferred by the goats were classified as unpalatable, which were found three in number.

Thus, the demonstration of utilization of unutilized land for livelihood security of under employed youths for integrated goat production with negligible inputs, was made a successful event on peoples participation. Interested livestock owners often visit to observe the demonstration of "zero to negligible budget" integrated goat husbandry system (Bhar, 2018). A training was also arranged for goat farmers on 16.08.2018 to 18.10.2018 (Banerjee et al., 2018). All the trainees (10 in number) were extremely interested to have demonstration on the "zero to negligible budget" integrated grass land development programme as a tool for utilization of unutilized land for integrated goat production on addressing the livelihood security of underemployed youths. Moreover, the concept of Integral Humanism has also been applied on integrating the local people to make the programme peoples participatory. The model developed on taking necessary help of our self help group personnel (SHG) on people's participation on conducting Swachh Bharat Abhiyan (SBA) is now helping us on solving some of the burning problems (mentioned below) of semi-intensive goat farming.

Saving the labour manpower,

Input cost of feeding under intensive system has been reduced significantly. 
Table.1 Classification of naturally grown grasses and weeds

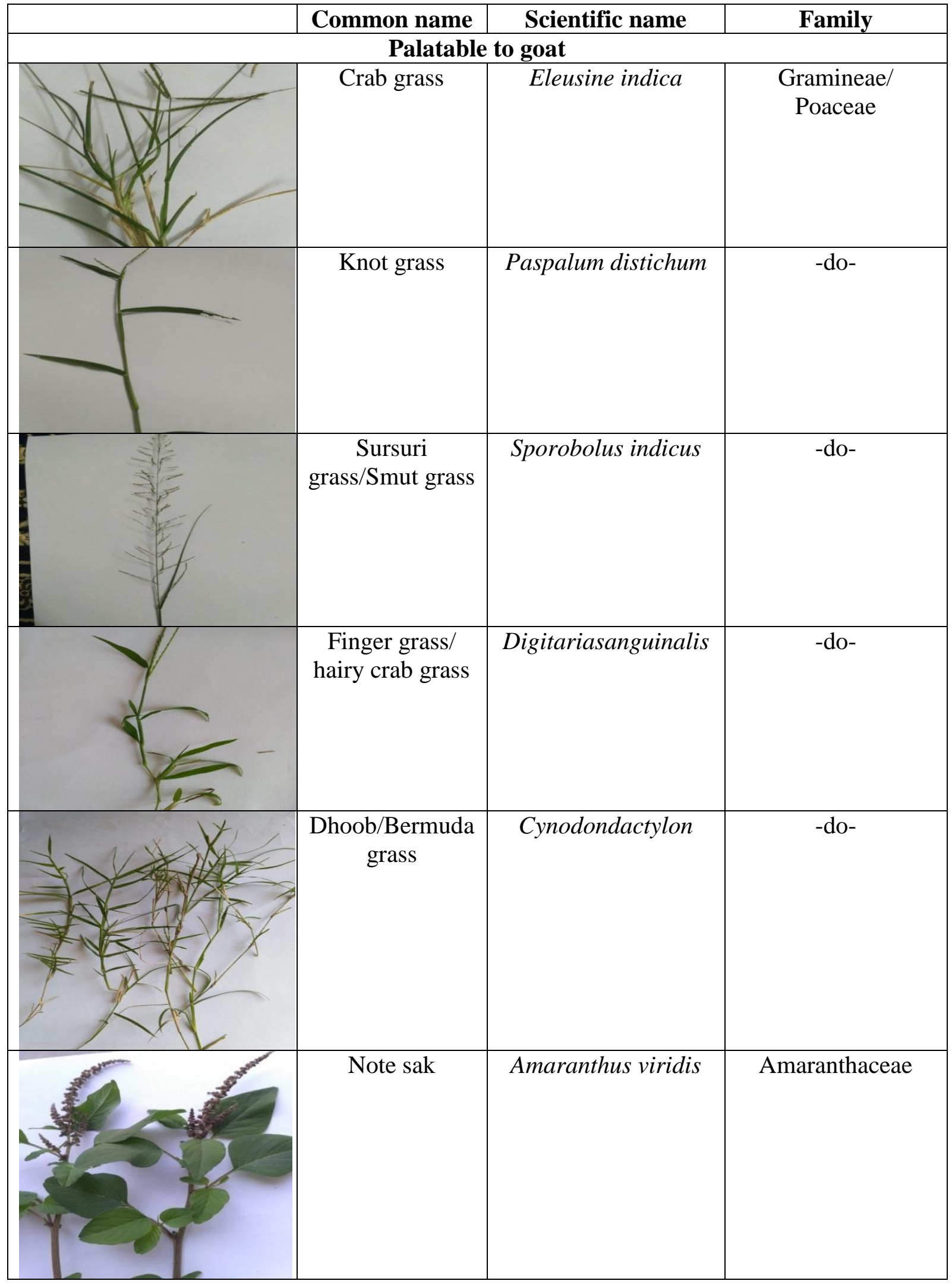




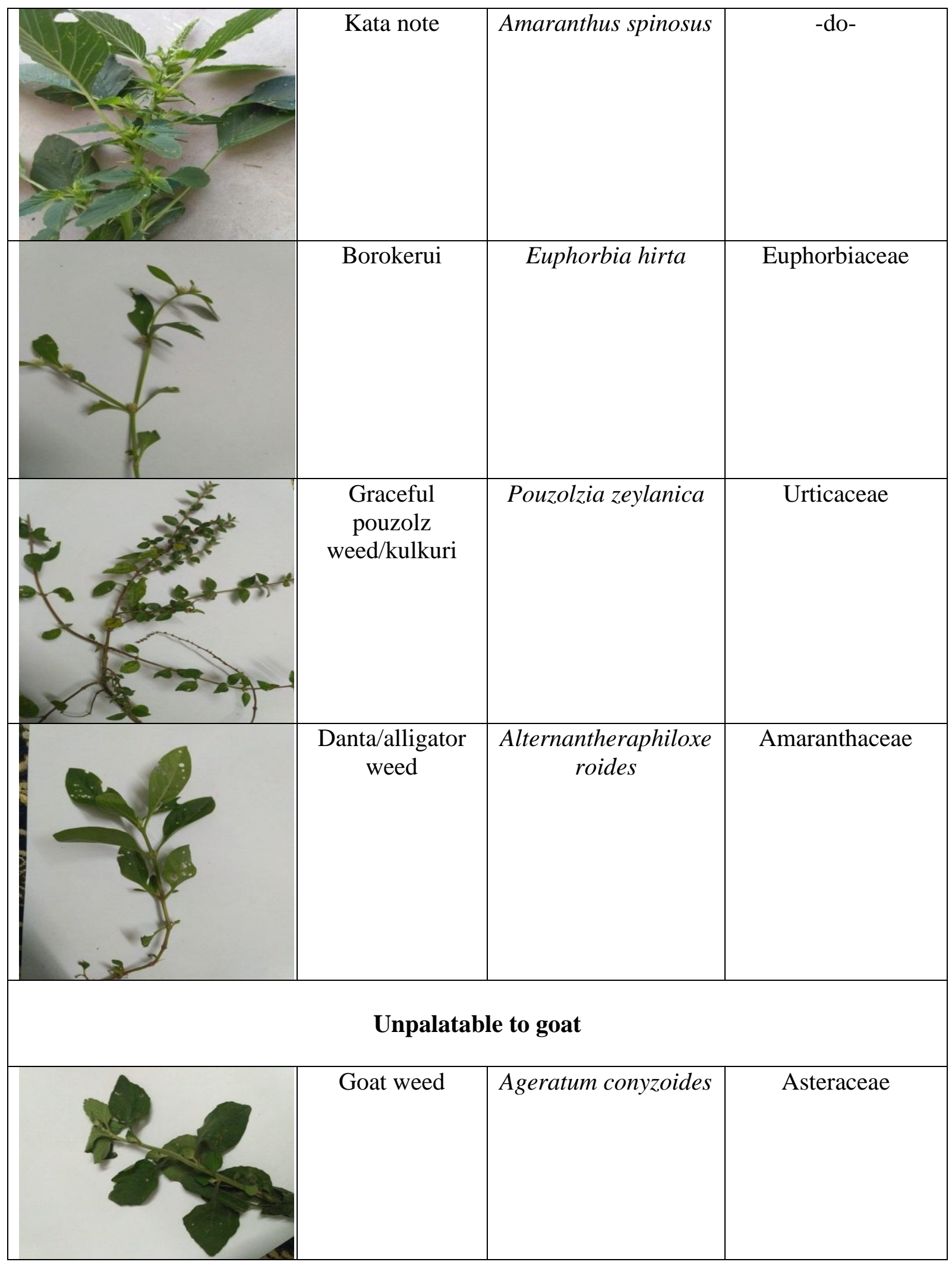


Int.J.Curr.Microbiol.App.Sci (2019) 8(11): 920-927

\begin{tabular}{|l|c|c|}
\hline & Lantana & Lantana camera \\
\hline \\
\hline
\end{tabular}

Fig.1 Demonstration plot for rotational grazing
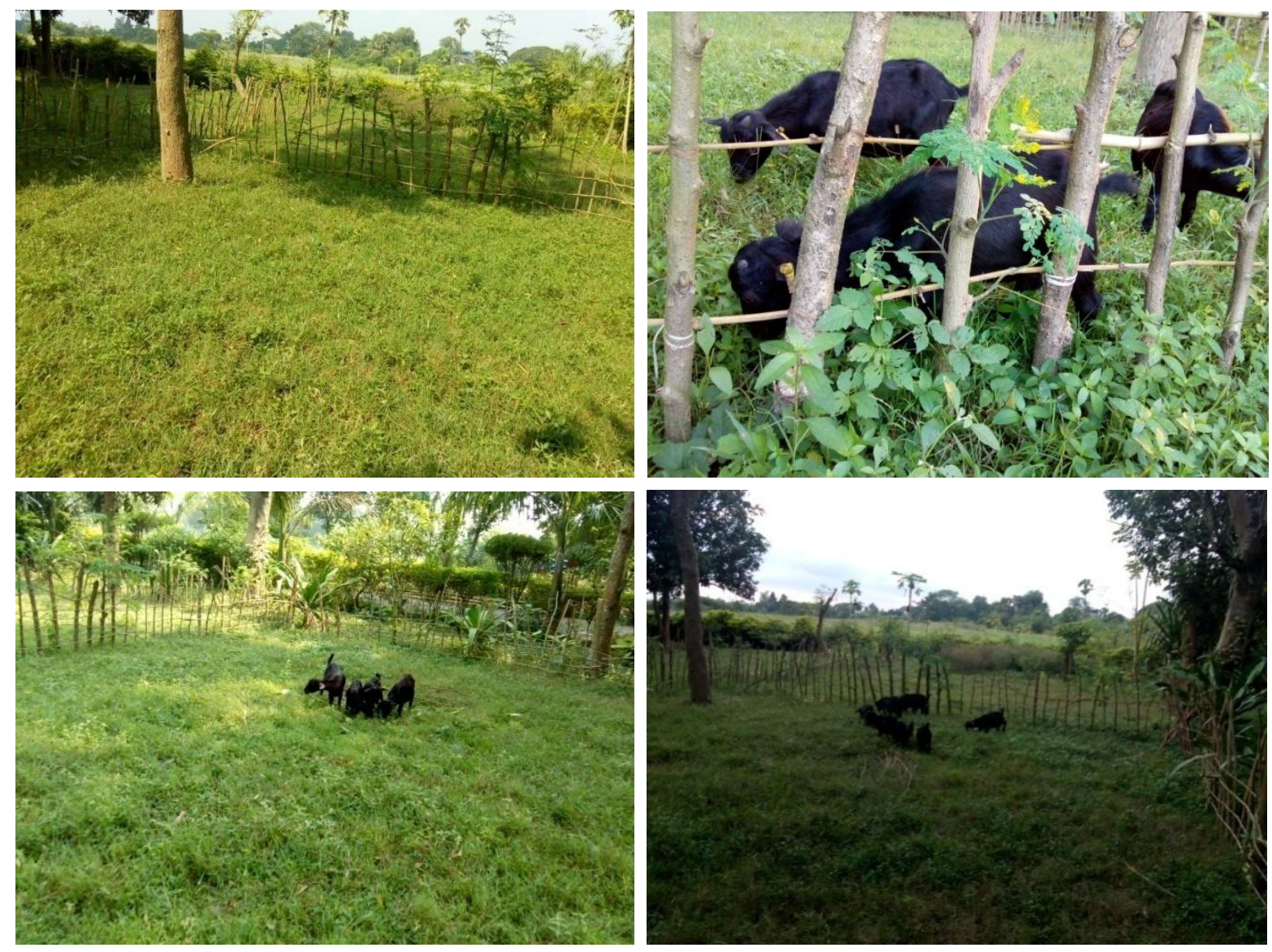
The goats are more protected and safe from the attack of wild animals (i.e., fox).

Help in demonstrating employment generation on addressing livelihood security of under employed youths and farmers as recommended by RAC and committed in our service project.

Now, requests are received for replication of the model in other farms or sectors. This is in reference of further application of integrated farming system model developed by Negi et al., (2015) and Bhar et al., (2017) and demonstrated in recently organised training programme on chhagolpalan (Bhar, 2018).

Interesting researchable observations related to Animal Nutrition and integrated farming are being recorded out of the model developed at North West Himalayan Region (Negi, et al., 2015) and replicated at eastern region without any expenditure (i.e., almost on zero to negligible budget) etc.

Unutilized/Underutilized land in organised and unorganised set up could be utilized on application of such model for addressing the livelihood security of under employed youths. Integrated goat husbandry with negligible inputs, seems to be one of the viable alternatives for addressing the livelihood security of landless to marginal farmers. Moreover, "transfer of scientific technology \& model or packages of practices from one place to other place" have been implemented in place of the existing concept, "transfer of scientist from one place to other place." Now, huge portions of barren and under productive lands of Government and Private sectors can be made productive as a source of natural animal feed (specially for small ruminants) on application of the model, "zero to negligible monitory inputs". Further this model would be more pragmatic to the landless and marginal farmers and livestock owners to address their livelihood security through integrated farming along with animal nutrition.

\section{References}

Baigyanik Padhatite Chagol Palan. ICARIVRI Eastern Regional Station, 37 Belgachia Road, Kolkata-700037 (W.B.). 2018; pp.1-79.

Bhar, R., Pati, U. S., Panda, A. K., Naveen Kumar, Mane, B. G., Kannan A., Sharma, S.K., Sharma Arun, Sharma Rinku and Singh Birbal 2017. Studies on application of veterinary and agricultural technology along with Integral Humanism on socio-economic development in a tribal village, Karnarthu in Himachal Pradesh. 2nd National Conference of Society for Veterinary \& Animal Husbandry Extension (SVAHE)" during April, 1012, 2017 held at Faculty of Veterinary Sciences \& Animal Husbandry, Shere-Kashmir University of Agricultural Sciences \& Technology of Jammu (SKUAST-J), R S Pura. p. 222-223.

Bhar, Rasbehari 2018.Chagolpalanerahhar o poshanervaigyanik paddhati.In: Banerjee et al., 2018. Vaigyanik Padhatitechagalpalan, ICAR-IVRI Eastern Regional Station, 37 Belgachia. Pp. 16-20.

Negi, S. S., Lal Krishna, Singh, B., Sharma, O. P., Bhat, T. K. and Bhar, R. 2015. ICAR-IVRI Regional Station, Palampur, H.P.: Brief history and current status. In: $3^{\text {rd }}$ Biennial National Conference of Indian Academy of Veterinary Nutrition and Animal Welfare (IAVNAW) on $\left(04^{\text {th }}\right.$ to $5^{\text {th }}$ November, 2015) "Interventions in Livestock Production-cum-Health and Crop Mixed Farming for Natritional Security". Sharma, V.K., Sudesh Radotra, Sharma, Arun, Panda, A.K., Rani Daisy and Sharma, Vinod (Eds.). 
Indian Academy of Veterinary Nutrition and Animal Health and Department of Animal Nutrition,
CoVAS, CSKHPKV, Palampur, H.P., India. Pp. 186-189.

\section{How to cite this article:}

Bhar, R., D.C. Roy, M. Ghosh, G.P. Mandal, S. Naskar, T.K. Biswas, D. Mandal, P.S. Banerjee, B. Koli and Biswas, P. 2019. Utilization of Unutilized Land on Development of a Demonstration Plot for Rotational Grazing of Black Bengal Goats on Zero to Negligible Budget. Int.J.Curr.Microbiol.App.Sci. 8(11): 920-927. doi: https://doi.org/10.20546/ijcmas.2019.811.107 